\title{
Seropositivity of West Nile Virus Among Acute Febrile Patients in Southern Ethiopia
}

This article was published in the following Dove Press journal:

Infection and Drug Resistance

\author{
Daniel Eshetu (D) \\ Tigist Kifle ${ }^{2}$ \\ Bekalu Getahun Agaje ${ }^{3}$ \\ Agete Tadewos Hirigo ${ }^{4}$ \\ 'Yirgalem Hospital Medical College, \\ Department of Microbiology, Yirgalem \\ Town, Southern Ethiopia; ${ }^{2}$ Hawassa \\ University, College of Medicine and \\ Health Science, Comprehensive \\ Specialized Hospital, Hawassa City, \\ Southern Ethiopia; ${ }^{3}$ Hawassa University, \\ College of Medicine and Health Science, \\ Department of Optometry, Hawassa \\ City, Southern Ethiopia; ${ }^{4}$ Hawassa \\ University, College of Medicine and \\ Health Science, School of Medical \\ Laboratory Sciences, Hawassa City, \\ Southern Ethiopia
}

Background: West Nile virus (WNV) is one of the widely distributed arboviruses in the world, and it is a pathogen of both humans and animals. The evidence that supports the prevalence of the WNV infection in Ethiopia is very scarce. Hence, this study aimed to assess the seropositivity of WNV among patients with acute febrile illness.

Methods: This health institution-based descriptive cross-sectional study was conducted on 532 acute febrile patients from May to August 2016 in Arba Minch Zuria district selected public health facilities, Southern Ethiopia. A pre-structured questionnaire was used to collect socio-demographic and clinical related information of the participants through convenient sampling techniques. In addition, trained nurses who were working in the health centers were responsible for interviewing acute febrile patients. About $5 \mathrm{~mL}$ of venous blood was collected aseptically from each of the study participants for the screening of the WNV immunoglobulin $\mathrm{G}(\mathrm{IgG})$ and immunoglobulin $\mathrm{M}$ (IgM) antibodies using indirect immunofluorescence technique (IIFT) as per manufacturer's protocol. Data analysis was done using statistical package for social sciences (SPSS) version 20 software and the results were presented by frequency and percentage using tables.

Results: A total number of 529 acute febrile patients (42.7\% males and $57.3 \%$ females) were enrolled in the study with a response rate of $99.4 \%$. The overall $7.4 \%$ of acute febrile patients were seropositive for WNV-specific IgG and the rate was higher in males $(9.7 \%)$ when compared to females $(5.6 \%)$. While the overall $4.5 \%$ were seropositive for WNVspecific IgM and the rate was $6.6 \%$ in males and $3.0 \%$ in females.

Conclusion: The finding of this study is an important alarm for clinicians/physicians to diagnose febrile patients in the divergent direction including with the diagnosis of flaviviruses. In addition, the finding will further contribute to understanding the epidemiology of WNV fever in Ethiopia and it will play a role in the delivery of public health measures to decrease the risk of WNV exposure in the areas.

Keywords: West Nile virus, acute febrile patients, Arba Minch Zuria district, Southern Ethiopia

\section{Introduction}

West Nile virus (WNV) is one of the widely distributed arboviruses globally, and a pathogen of public health at a significant rate both in humans and animals. ${ }^{1}$ This mosquito-borne virus has been categorized in the genus Flavivirus within the family of Flaviviridae. ${ }^{2}$

WNV was first discovered and isolated from the blood of a woman in Uganda $1937,{ }^{3}$ again similar cases were documented in Egypt and Israel in the early 1950s, whereas it was reported from South Africa in the 1970s and France in the 1960s. ${ }^{4}$ In
Correspondence: Daniel Eshetu Yirgalem Hospital Medical College, Department of Microbiology, P.O. Box

184, Yirgalem, Ethiopia

Tel +25I-917-867385

Email danieshetu@gmail.com 
addition, WN fever raised in the 1990s, the outbreak has occurred in Mediterranean Basin and some parts of Europe, ${ }^{5}$ and WNV has also emerged in New York City and over 20,265 patients developed neurological sign and symptoms, and about 1,783 cases have died including a high mortality rate of birds. ${ }^{6-8}$ Moreover, the WNV disease including encephalitis spread greatly in Europe, Asia and Oceania. ${ }^{9}$ Massive outbreaks was happened in Romania in $1996,{ }^{10}$ and Russia in $1999 .{ }^{11}$ Further, WN fever and encephalitis have been reported in Europe in the 21 century. $^{12}$

Patients infected with WNV may develop signs and symptoms on 3-14 days after the bite of a WNV-infected mosquito, while in severe cases may be biphasic and have symptoms prolonged up to 60 days. ${ }^{13}$ The infected patients develop WN fever that varies from asymptomatic infections (mild acute febrile illness), and some patients may develop neurological diseases that include meningitis, encephalitis, and acute flaccid paralysis. ${ }^{13,14}$ Of the $80 \%$ of human infections are subclinical, while symptomatic patients can vary from influenza-like symptoms to neurotropic manifestations. ${ }^{15}$ While about $20 \%$ of the infections cause a febrile illness in affected patients and $1 \%$ of infections may lead to neuro-invasive disease. ${ }^{8,16}$ The mortality rate of $\mathrm{WNV}$ infection ranges from $4 \%$ to $14 \%,{ }^{8,10,17}$ however, the rate might increase from $15 \%$ to $29 \%$ in elder patients. ${ }^{18}$ This virus can be categorized as at least five phylogenetic lineages, ${ }^{19}$ and only lineage- 1 and 2 have been associated with significant epidemics in human beings. $^{20,21}$ On the other hand, a lack of an effective prophylactic vaccine or antiviral therapeutic situations might lead to more epidemics of WNV infection in different geographic locations in the world. ${ }^{22}$

Further, the evidence to support the prevalence of WNV in Ethiopia is very scarce. Therefore, the present study aimed to assess the seropositivity of WNV among patients with acute febrile infections in Arba Minch Zuria district, Southern Ethiopia.

\section{Methods}

\section{Study Settings and Study Population}

This health institutions-based cross-sectional study was conducted from May to August 2016 in selected public health facilities of Arba Minch Zuria district, Gamo Gofa Zone, Southern Ethiopia. Arba Minch town is located 505 $\mathrm{Km}$ from Addis Ababa (the capital city of Ethiopia) and $275 \mathrm{~km}$ from Hawassa, which is the capital city of the
Southern Nation, Nationalities Peoples Region (SNNPR). According to 2007, Central Statistics Agency of Ethiopia (CSA), the total population in the district woreda was 165,680 of which 82,751 were males and 82,929 were female. In addition, Arba Minch is found in Great Rift Valley and located at 5.57-6.72 ${ }^{\circ}$ North latitude, 36.38$37.99^{\circ}$ East longitude, and the altitude ranges from 501 to 3500 meters above sea level. The area is Kolla (lowland) with the average annual rainfall and temperature of $1300.5 \mathrm{~mm}$ and $15.1^{\circ} \mathrm{C}-27.5^{\circ} \mathrm{C}$, respectively (Figure 1). Patients with acute febrile illness $\left(\geq 37.5^{\circ} \mathrm{C}\right.$ axillary temperature) at the initial assessment with less than 7 days of onset of symptoms were eligible for the study. Moreover, three public health centers (Lante, Shele and Birbir) from the district were selected and in total 532 acute febrile cases of outpatient departments were enrolled through convenient sampling techniques. In addition, sociodemographic and clinical related information of the study participants were collected by pre-structured questionnaire through the interviewer-administered approach. Moreover, the interview of the study participants was done by trained nurses who were working in the selected health centers.

Most of the time clinicians/physicians request Widal Weil Felix (WWF) tests for typhoid and typhus fever and blood films for haemoparasites to treat acute febrile patients. If the laboratory results become non-reactive for WWF or negative for haemoparasites, clinicians urged to treat these patients based on signs and symptoms due to lack of further diagnosis concerning arboviruses. Arba Minch Zuria district found in the rift valley and febrile diseases like dengue fever, WNV fever, yellow fever, and other related arboviruses were reported from the nearby ecological zone, ${ }^{23}$ and also the district is closer to Kenya and the prevalence of arboviruses also was reported from Kenya. ${ }^{24}$ However, the laboratory diagnosis of arboviruses disease is still not practical in public health service delivery institutions. That is why the current study aimed to assess WNV infection in acutely febrile patients in the mentioned ecological areas.

\section{Specimen Collection and Laboratory Diagnosis}

About $5 \mathrm{~mL}$ of venous blood was collected aseptically from each study participant using plain-red top test tube. Blood specimens were left undisturbed for $30 \mathrm{mins}$ at room temperature for proper clotting and then clotted samples were centrifuged at 2500-3000rpm for 5-10 


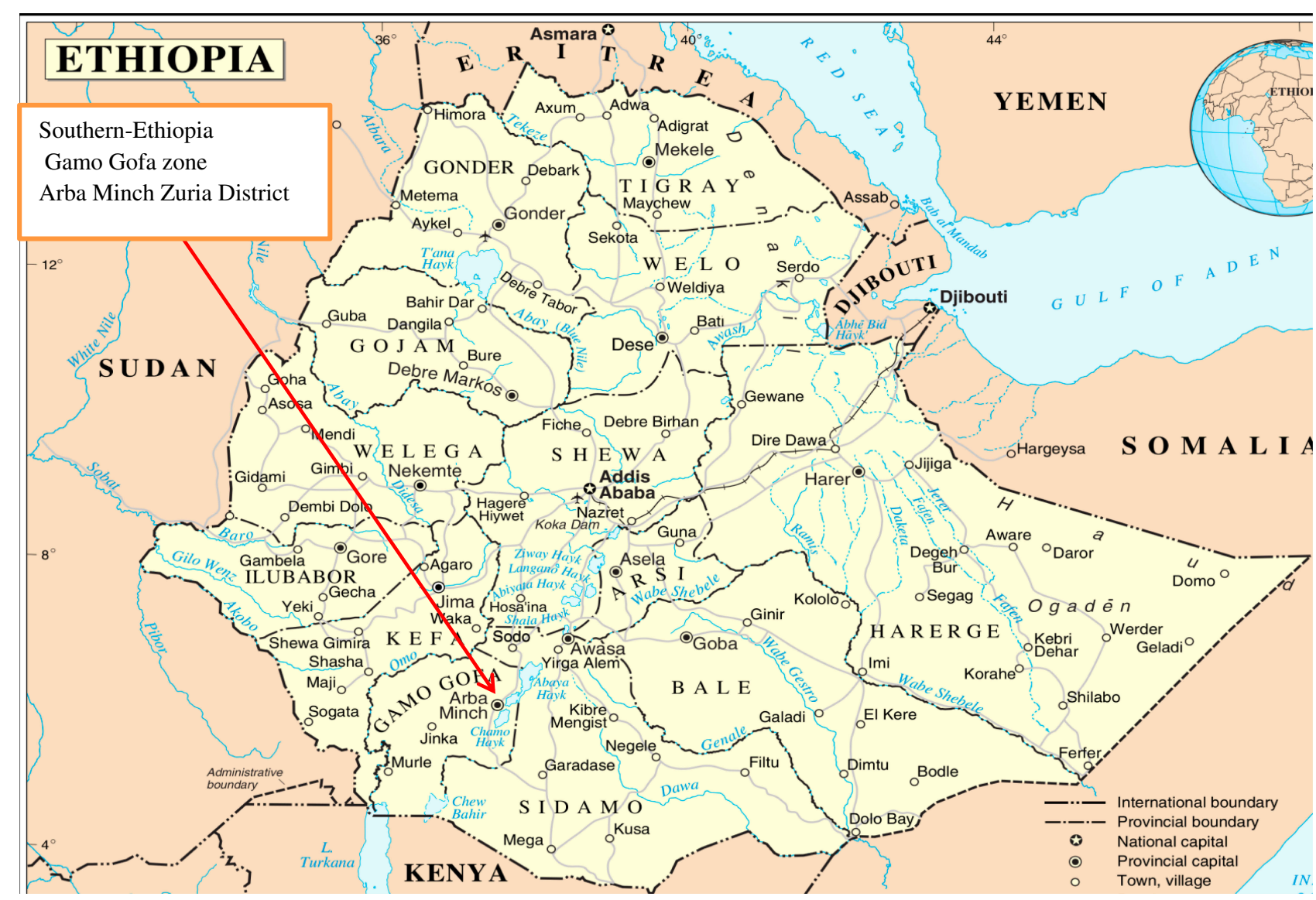

Figure I Map of Arba Minch Zuria district in Gamo Gofa zone, Southern Ethiopia.

mins at room temperature. Following this, the serum sample was separated into multiple Nunc tubes for each patient and then transported to Armauer Hansen Research Institute (AHRI) laboratory by liquid nitrogen cold-chain system for laboratory diagnosis. Moreover, the serum sample of each patient was screened for the presence/absence of WNV-specific IgG and WNV-specific IgM antibodies using indirect immunofluorescence test (IIFT) (EUROIMMUN AG, Luebeck, Germany) as per manufacture's protocol. Initially, serum was diluted to 1:10 with buffer and $30 \mu \mathrm{L}$ of diluted serum added to each of the two reaction fields on a BIOCHIP slide. Each field contained two BIOCHIPS, one with WNV-infected cells and the other with uninfected cells and incubated at room temperature for $30 \mathrm{mins}$ in the dark place. Then, cells were exposed to either $6 \mathrm{M}$ urea solution or phosphate-buffered saline-Tween for 5 mins. After washing with phosphate-buffered saline-Tween, cells were incubated with fluorescein-labeled anti-human globulin for 30 mins and again washed with buffer. After drying, the slides were viewed at the $20 \mathrm{x}$ magnification objective of fluorescent microscopy. In a definite positive reaction, the cytoplasm of infected cells viewed fine to coarse granular fluorescence and inclusion bodies in some cells. The presence of $\operatorname{IgG} / \operatorname{IgM}$ antibodies was inferred by the absence or substantial decrease of fluorescence of urea treated cells compared with the buffer-treated controls.

\section{Statistical Analysis}

Data were double entered in REDCap data software (8.0.3. @ 2018, Vanderbilt University) and cleaned data exported to Statistical Package for Social Sciences (SPSS) version 20 for statistical analysis. Descriptive statistics were used and the results were presented by frequency and percentage using tables.

\section{Ethical Considerations}

The study was ethically approved by the institutional review board (IRB) of Hawassa University College of Medicine and Health Sciences. Then, the official letter was submitted to the SNNPR Health bureau to get a supportive letter of permission and then a supportive 
letter was submitted to the selected Health facilities before goes to data collection. All the study participants were well informed about the procedure of the study. Then, written informed consent was obtained from the study participants or parents/legal guardians for those ages less than 18 years old. The confidentiality of the participants' information was strictly preserved.

\section{Results}

Totally 532 acute febrile patients were approached, 529 (42.7\% males and 57.3\% females) were enrolled in the study with a response rate of $99.4 \%$. Nearly half $(47.5 \%)$ of the participants were aged between 15 and 30 years. The majority $(86.8 \%)$ of participants were rural inhabitants. The overall $7.4 \%$ of febrile patients were seropositive for WNVspecific $\mathrm{IgG}$ and the rate was higher in males (9.7\%) when compared to females $(5.6 \%)$. While the overall $4.5 \%$ of febrile patients were seropositive using WNV-specific IgM and the rate was $6.64 \%$ in males and $3.0 \%$ in females (Table 1).

The seropositivity rate among patients who did not use bed-net was higher when compared to those used bed-nets (12.4\% vs 5.0\% for WNV-specific IgG and $9.47 \%$ vs $2.2 \%$ for WNV-specific IgM), respectively. Similarly, the seropositivity rate was higher among patients with recent mosquitos bite $(6.5 \%)$ when compared with those who have no recent bite $(2.8 \%)$ by IgM (Table 2$)$.

\section{Discussion}

The findings of this study indicated the overall $7.4 \%$ of acute febrile patients were seropositive for WNV-specific IgG. In addition, $9.7 \%$ of males and $5.6 \%$ of females were seropositive for the WNV-specific IgG. While the overall
$4.5 \%$ of the patients were seropositive for WNV-specific $\operatorname{IgM}$ and the rate was $6.64 \%$ in males and $3.0 \%$ in females.

The finding of the current study indicated that $7.4 \%$ of febrile patients were seropositive for by WNV-specific IgG and the finding was comparable with the study conducted in Ilorin, Nigeria that was $7.5 \%{ }^{25}$ However, the higher rates were reported by several studies from asymptomatic and febrile patients: like $10.2 \%$ and $9.6 \%$ in Kenya, ${ }^{24,26}$ $73.2 \%$ and $80.1 \%$ in Nigeria, ${ }^{27,28} 27.9 \%$ in Ghana, ${ }^{29}$ $27.2 \%$ in Gabon with different prevalence rate in diverse ecosystems like $23.7 \%$ in forested regions, $21.8 \%$ in savanna and $64.9 \%$ in the lakes region, ${ }^{30}$ and $59 \%$ in the Democratic Republic of Congo. ${ }^{31}$ On the other hand, the finding of this study was higher than the studies conducted in the South Omo zone, Southern Ethiopia, ${ }^{23}$ Spain, ${ }^{32}$ United States, ${ }^{33}$ Greek, $^{34}$ and Libya. ${ }^{35}$ The prevalence rates in the depicted studies were $0.9 \%, 6.5 \%, 2.6 \%$, $2.5 \%$ and $2.7 \%$, respectively. The variations might be attributed to differences in the detection methods (sensitivity and specificity levels), the period of the studies, variability in climatic conditions or geographical locations and mosquitos (vectors) breeding seasons. In support, the individual's contact with mosquitoes also can differ significantly within and among population groups. ${ }^{36}$

The present study indicated $4.2 \%$ of febrile patients were seropositive for $\mathrm{WNV}$-specific IgM and this might reflect a recent infection of $\mathrm{WNV}$ or the presence of crossreactive antibodies with the infection of other flaviviruses. All positive results that obtained with the IgM assay should be confirmed by neutralizing antibody testing. ${ }^{37}$ In addition, WNV-specific IgG antibodies usually are detected shortly after IgM antibodies and it persists for

Table I Socio-Demographic Characteristics and Seropositivity of West Nile Virus

\begin{tabular}{|c|c|c|c|c|c|}
\hline \multirow[t]{2}{*}{ Characteristics } & \multirow[t]{2}{*}{ Total (\%) } & \multicolumn{2}{|l|}{ IgG Test } & \multicolumn{2}{|l|}{ IgM Test } \\
\hline & & IgG (+Ve) & IgG (-Ve) & $\operatorname{lgM}(+\mathrm{Ve})$ & $\operatorname{IgM}(-\mathrm{Ve})$ \\
\hline \multicolumn{6}{|l|}{ Sex } \\
\hline Male & $226(42.7)$ & $22(9.7)$ & 204(90.3) & $15(6.64)$ & $211(93.36)$ \\
\hline Female & $303(57.3)$ & $17(5.6)$ & $286(94.4)$ & $9(3.0)$ & 294(97.0) \\
\hline \multicolumn{6}{|l|}{ Age group, years } \\
\hline$<15$ & $80(15.13)$ & $7(8.7)$ & $73(91.3)$ & $3(3.75)$ & $77(96.25)$ \\
\hline $15-30$ & $25 \mathrm{I}(47.45)$ & $9(3.6)$ & $242(96.4)$ & $5(2.0)$ & $246(98.0)$ \\
\hline $31-45$ & $105(19.86)$ & $13(12.4)$ & $92(87.6)$ & $9(8.6)$ & $96(91.4)$ \\
\hline$>45$ & $93(17.58)$ & $10(10.7)$ & $83(89.3)$ & $7(7.5)$ & $86(92.5)$ \\
\hline \multicolumn{6}{|l|}{ Residence } \\
\hline Rural & $459(86.8)$ & $28(6.1)$ & $43 I(93.9)$ & $21(4.6)$ & $438(95.4)$ \\
\hline Urban & $70(13.2)$ & II(I5.7) & $59(84.3)$ & $3(4.3)$ & $67(95.7)$ \\
\hline
\end{tabular}


Table 2 West Nile Virus Infection with Different Variables Among Acute Febrile Patients

\begin{tabular}{|c|c|c|c|c|c|c|}
\hline \multirow[t]{2}{*}{ Characteristics } & \multirow[t]{2}{*}{ Response } & \multirow[t]{2}{*}{ Total (\%) } & \multicolumn{2}{|l|}{ IgG Test } & \multicolumn{2}{|l|}{ IgM Test } \\
\hline & & & IgG (+Ve) & IgG (-Ve) & $\operatorname{lgM}(+\mathrm{Ve})$ & $\operatorname{IgM}(-\mathrm{Ve})$ \\
\hline \multirow[t]{2}{*}{ Used bed-net at night } & Yes & $360(68.1)$ & $18(5.0)$ & $342(95.0)$ & $8(2.2)$ & $352(97.8)$ \\
\hline & No & $169(31.9)$ & $2 I(I 2.4)$ & I48(87.6) & $16(9.47)$ & $153(90.53)$ \\
\hline \multirow[t]{2}{*}{ Presence of stagnant water nearby } & Yes & $172(32.5)$ & $23(I 3.4)$ & $149(86.6)$ & $10(5.8)$ & $162(94.2)$ \\
\hline & No & $357(67.5)$ & $16(4.48)$ & $34 I(95.52)$ & $14(3.9)$ & $343(96.1)$ \\
\hline \multirow[t]{2}{*}{ The habit of outdoor stay during the night time } & Yes & $4 \mid 4(78.3)$ & $21(5.1)$ & $393(94.9)$ & $15(3.6)$ & $399(96.4)$ \\
\hline & No & $115(21.7)$ & $18(I 5.6)$ & $97(84.4)$ & $9(7.8)$ & 106(92.2) \\
\hline \multirow[t]{2}{*}{ History of a recent mosquito bite } & Yes & $246(46.5)$ & $19(7.7)$ & $227(92.3)$ & $16(6.5)$ & $230(93.5)$ \\
\hline & No & $283(53.5)$ & $20(7.1)$ & $263(92.9)$ & $8(2.8)$ & $275(97.2)$ \\
\hline
\end{tabular}

many years. Therefore, the presence of IgG antibodies in the febrile patients' sample alone is the only evidence of the previous infection and clinically compatible cases with the presence of IgG, while the presence of IgM also needs the evaluation for other etiologic agents of flaviviruses. ${ }^{37,38}$

\section{Limitation of the Study}

Since the study nature is cross-sectional and suggesting that it cannot provide adequate evidence on cause and effect relationship among dependent and independent variables. In addition, we used indirect immunofluorescence test (IIFT) to determine the seropositivity rate; however, a different rate might be observed if other detection techniques like Enzyme-linked immunosorbent Assay (ELISA), reverse transcriptase-polymerase chain reaction (RT-PCR) or nucleic acid amplification tests (NATs) were used. Another limitation, we did not perform a neutralization assay, such as a plaque reduction neutralization test (PRNT) for those patients who were seropositive for IgM antibodies to differentiate whether the infection is current for WNV or cross-reactive with other flaviviruses. Irrespective of the revealed limits, the study provides supportive information in the scarce data situation of Ethiopia concerning WNV infection.

\section{Conclusion}

The finding of the study is an important alarm for clinicians/physicians to think in divergent direction for such acute febrile patients to suspect of WNV(flaviviruses) infection and alerts responsible body for the provision of reliable detection techniques for the diagnosis of infection. In addition, the finding will further contribute to understanding the epidemiology of WNV fever in Ethiopia and it will play a role in the delivery of public health measures to decrease the risk of WNV exposure in the areas. Further, an in-depth study is required to assess the prevalence of $\mathrm{WNV}$ and its associated factors in a large scale using more sensitive and specific diagnostic techniques.

\section{Abbreviations}

IIFT, indirect immunofluorescence test; IgG, immunoglobulin G; IgM, immunoglobulin M; WNV, West Nile virus; SPSS, statistical package for social sciences.

\section{Data Sharing Statement}

All data set of this study is not openly accessible but it can be accessible with a reasonable request from the corresponding author.

\section{Acknowledgments}

We want to acknowledge the Armauer Hansen Research Institute for financial as well as laboratory supplies support. Our gratefulness is also extended to health professionals of the study selected health centers for their great support during data collection and the study subjects for their voluntary contribution to the study.

\section{Author Contributions}

All authors contributed toward data analysis, drafting and revising; gave final approval of the final version to be published and agree to be responsible for all aspects of the work.

\section{Disclosure}

The authors declare that they have no conflicts of interest in this work. 


\section{References}

1. Shomaker TS, Green EM, Yandow SM. Perspective. One Health: a compelling convergence. Acad Med. 2013;88(1):49-55. doi:10.1097/ACM.0b013e31827651b1

2. Campbell GL, Marfin AA, Lanciotti RS, Gubler DJ. West Nile virus. Lancet Infect Dis. 2002;2(9):519-529. doi:10.1016/S1473-3099(02) 00368-7

3. Smithburn KC, Hughes TP, Burke AW, Paul JH, African A. A neurotropic virus isolated from the blood of a native of Uganda. Am J Trop Med Hyg. 1940;s1-20:471-492.

4. Murgue B, Murri S, Triki H, Deubel V, Zeller HG. West Nile in the Mediterranean basin: 1950-2000. Ann N Y Acad Sci. 2001;951:117-126. doi:10.1111/j.1749-6632.2001.tb02690.x

5. Urgue B, Zeller H, Deubel V. The ecology and epidemiology of West Nile Virus in Africa, Europe and Asia. In Japanese encephalities and west nile viruses 2002 (pp 195-221): Springer Berlin Heidelberg.

6. Huba'lek Z, Halouzka J. West Nile fever-a reemerging mosquito-borne viral disease in Europe. Emerg Infect Dis. 1999;5:643-650. doi:10.3201/eid0505.990505

7. Asnis DS, Conetta R, Waldman G, Teixera AA.The West Nile Virus encephalitis outbreak in theUnited States (1999-2000). Ann N Y Acad Sci.2006;951:161-171. doi:10.1111/j.1749-6632.2001.tb02694.x

8. Nash D, Mostashari F, Fine A, Miller J, O'Leary D, Murray K, et al. The outbreak of West Nile Virus infection in the New York City Area in 1999. $N$ Engl $J$ Med. 2001;344:1807-1814. doi:10.1056/ NEJM200106143442401

9. Rossi SL, Ross TM, Evans JD. West Nile Virus. Clin Lab Med. 2010;30:47-65. doi:10.1016/j.cll.2009.10.006

10. Tsai T, Popovici F, Cernescu C, Campbell G, Nedelcu N. West nile encephalitis epidemic in southeastern Romania. Lancet. 1998; 352:767-771.

11. Platonov AE, Shipulin GA, Shipulina OY, et al. Outbreak of West Nile virus infection, Volgograd Region, Russia, 1999. Emerg Infect Dis. 2001;7:128-132. doi:10.3201/eid0701.010118

12. Sambri V, Capobianchi M, Charrel R, et al. West Nile virus in Europe: emergence, epidemiology, diagnosis, treatment, and prevention. Clin Microbiol Infect. 2013;19:699-704. doi:10.1111/ 1469-0691.12211

13. Hayes EB, Sejvar JJ, Zaki SR, Lanciotti RS, Bode AV, Campbell GL. Virology, pathology, and clinical manifestations of West Nile virus disease. Emerg Infect Dis. 2005;11:1174-1179. doi:10.3201/ eid1108.050289b

14. Kramer LD, Li J, Shi P-Y. West Nile virus. Lancet Neurol. 2007;6:171-181. doi:10.1016/S1474-4422(07)70030-3

15. Suthar MS, Diamond MS, Jr GM. West Nile virus infection and immunity. Nat Rev Microbiol. 2013;11:115-128. doi:10.1038/ nrmicro2950

16. West Nile Virus Activity-United States, 2006. JAMA. 2007;298:619. doi:10.1001/jama.298.6.619

17. Chowers MY, Lang R, Nassar F, Ben-David D, Giladi M, Rubinshtein E, et al. Clinical characteristics of the West Nile fever outbreak, Israel, 2000. Emerging infectious diseases. 2001;7(4):675. doi:10.3201/eid0704.010414

18. Petersen LR, Marfin AA. West Nile Virus. A primer for the clinician. Ann Intern Med. 2002;137:173-179. doi:10.7326/0003-4819-1373-200208060-00009

19. May FJ, Davis CT, Tesh RB, Barrett AD. Phylogeography of West Nile virus. J Virol. 2011;85(6):2964-2974. doi:10.1128/JVI.01963-10

20. Murray KO, Mertens E, Despres P. West Nile virus and its emergence in the United States of America. Vet Res. 2010;41:67. doi:10.1051/ vetres/2010039
21. Lanciotti RS, Roehrig JT, Deubel V, et al. Origin of the West Nile Virus responsible for an outbreak of encephalitis in the Northeastern United States. Science. 1999;286:2333-2337. doi:10.1126/science. 286.5448.2333

22. Patel H, Sander B, Nelder MP. Long-term sequelae of West Nile virus-related illness: a systematic review. Lancet Infect Dis. 2015;15 (8):951-959. doi:10.1016/S1473-3099(15)00134-6

23. Tsegaye MM, Beyene B, Ayele W, et al. Sero-prevalence of yellow fever and related Flaviviruses in Ethiopia: a public health perspective. BMC Public Health. 2018;18(1):1011. doi:10.1186/s12889-0185726-9

24. Chepkorir E, Tchouassi DP, Konongoi SL, et al. Serological evidence of Flavivirus circulation in human populations in Northern Kenya: an assessment of disease risk 2016-2017. Virol J. 2019;16(1):65. doi:10.1186/s12985-019-1176-y

25. Kolawole OM, Adelaide G, Emergence O. Associated Risk Factors of Vector-Borne West Nile Virus Infection in Ilorin, Nigeria. J Arthropod Borne Dis. 2018;12(4):341-350.

26. Inziani M, Adungo F, Awando J, et al. Seroprevalence of yellow fever, dengue, West Nile and chikungunya viruses in children in Teso South Sub-County, Western Kenya. Int J Infect Dis. 2020;9:104-110. doi:10.1016/j.ijid.2019.11.004

27. Sule WF, Oluwayelu DO. Serologic Evidence of Exposure to West Nile Virus among Humans in Ibadan, Southwestern Nigeria. Sudan $J M S .2016 ; 11(3): 111-123$.

28. Baba MM, Saron MF, Diop O, Mathiot C, Adeniji JA, Olaleye OD. West Nile virus in mosquitoes and febrile patients in a semi-arid zone, Nigeria. J Am Sci. 2006;2(2):28-34.

29. Wang W, Sarkodie F, Danso K, et al. Seroprevalence of west nile virus in Ghana. Viral Immunol. 2009;22:17-22.

30. Pourrut X, Nkoghé D, Paweska J, Leroy E. First serological evidence of West Nile virus in human rural populations of Gabon. Virol J. 2010;7:132. doi:10.1186/1743-422X-7-132

31. Nur YA, Groen J, Heuvelmans H, Tuynman W, Copra C, Osterhaus AD. An outbreak of West Nile fever among migrants in Kisangani, Democratic Republic of Congo. Am J Trop Med Hyg. 1999;61:885-888. doi:10.4269/ajtmh.1999.61.885

32. Piron M, Plasencia A, Fleta-Soriano E, et al. Low seroprevalence of West Nile Virus in Blood Donors from Catalonia, Spain. Vector Borne Zoonotic Dis. 2015;15(12):782-784. doi:10.1089/vbz.2015. 1787

33. Mostashari F, Bunning ML, Kitsutani PT, et al. Epidemic West Nile encephalitis, New York, 1999: results of a household-based seroepidemiological survey. Lancet. 2001;358(9278):261-264. doi:10.1016/ S0140-6736(01)05480-0

34. Hadjichristodoulou C, Pournaras S, Mavrouli M, et al. West Nile Virus seroprevalence in the Greek Population in 2013: a nationwide cross-sectional survey. PLoS One. 2015;10(11):e0143803. doi:10.13 71/journal.pone. 0143803

35. Shaibi T, Saadawi WK, Aghila H, Annaja BB. Prevalence of IgG antibodies for the West Nile virus in human population in Tripoli, Libya. J Vector Borne Dis. 2017;54:183-186.

36. Liu A, Lee V, Galusha D, et al. Risk factors for human infection with West Nile virus in Connecticut: a multi-year analysis. Int $J$ Health Geogr. 2009;8:67. doi:10.1186/1476-072X-8-67

37. CDC. WNV Antibody Testing. Available from: https://www.cdc.gov/ westnile/healthcareproviders/healthCareProviders-Diagnostic.html. Accessed August 25, 2019.

38. Turell MJ, O'Guinn ML, Dohm DJ, Jones JW. Vector competence of North American mosquitoes (Diptera: culicidae) for West Nile virus. J Med Entomol. 2001;38(2):130-134. doi:10.1603/0022-2585-38.2. 130 


\section{Publish your work in this journal}

Infection and Drug Resistance is an international, peer-reviewed openaccess journal that focuses on the optimal treatment of infection (bacterial, fungal and viral) and the development and institution of preventive strategies to minimize the development and spread of resistance. The journal is specifically concerned with the epidemiology of

Submit your manuscript here: https://www.dovepress.com/infection-and-drug-resistance-journa| antibiotic resistance and the mechanisms of resistance development and diffusion in both hospitals and the community. The manuscript management system is completely online and includes a very quick and fair peerreview system, which is all easy to use. Visit http://www.dovepress.com/ testimonials.php to read real quotes from published authors. 